\title{
Atzoko baliabideak, biharko osasuna: ardo-hondakinak eta kannabisa
}

\author{
(Yesterday's tools, tomorrow's health: wine wastes \\ and cannabis)
}

Oier Aizpurua-Olaizola*, Patricia Navarro, Nestor Etxebarria,
Aresatz Usobiaga

Kimika Analitikoa Saila, Euskal Herriko Unibertsitatea (UPV/EHU),

Sarriena auzoa z/g, 48940 Leioa

*oier.aizpurua@ehu.es

DOI: $10.1387 /$ ekaia.17845

Jasoa: 2017-05-15

Onartua: 2017-06-26

Laburpena: Tesi hau bi zutabe nagusitan banatzen da. Lehenengoan, ardo-hondakinen balioa handitzeko metodologia bat garatu genuen. Lehenik, ardo-hondakinetatik polifenolak eta gantz-azidoak, bakoitza bere aldetik, erauzi genituen jariakin gainkritikoak erabiliz. Polifenolak ez dira oso egonkorrak, ordea, eta gorputzean bioeskuragarritasun baxua dute. Arazo horiek konpontzeko, polifenolak mikrokapsularatzeko teknika bat garatu genuen. Bigarren zutabean, etorkizun hurbilean kannabisa sendagai bezala erabili ahal izateko, 3 urrats eman genituen. Alde batetik, landare ezberdinak efektu ezberdinekin lotzea ahalbide dezakeen landareen kannabinoideen hatz-marka osatzeko analisi-teknika garatu genuen. Bestetik, gernuan eta plasman kannabinoideak eta euren metabolitoak kuantifikatzeko metodo bat ere garatu genuen. Azkenik, konposatu puruen eta landare mota jakinen produkzioa optimizatzeko, kimiotipo ezberdineko landareen hazkuntzan zeharreko kannabinoideen eta terpenoen garapena aztertu genuen.

Hitz gakoak: Ardo-hondakinak, jariakin gainkritiko bidezko erauzketa, mikrokapsularatzea, gantz-azidoak, polifenolak, kannabisa, hatz-marka, landare-hazkuntza, kannabinoideak, terpenoak.

Abstract: This thesis was divided in two lines of research. On the one hand, supercritical fluid extraction was successfully applied to a sequential fractionation of fatty acids and polyphenols from wine wastes. Unfortunately, polyphenols have poor long-term stability and poor bioavailability, so they were microencapsulated. On the other hand, 3 different studies were done around medical use of cannabis. Firstly, in order to correlate plants with their physiological effects, an analysis method was developed to establish the cannabinoid fingerprinting of different cannabis plants. A method for the quantification of major cannabinoids and their metabolites in human urine and plasma was 
Oier Aizpurua-Olaizola, Patricia Navarro, Nestor Etxebarria, Aresatz Usobiaga

also developed. Finally, in order to optimize the production of bioactive compounds, the evolution of cannabinoid and terpene content of different chemotype plants during their growth was studied.

Keywords: Wine wastes, supercritical fluid extraction, microencapsulation, fatty acids, polyphenols., Cannabis, fingerprinting, plant-growing, cannabinoids, terpenes .

\section{SARRERA}

Abiaduraren aroan bizi gara, gauzak hamar urtean aurreko 50 urteetan baino gehiago aldatzen diren aroan, mundua abiadura zorabiagarri batean biraka dabilenez eta bertatik ezin jaitsi garenez, geu ere erritmo horretan lasterka bizi garen aroan, egunari orduak falta zaizkiolako McDonalds-ean korrika eta presaka hanburgesa bat jaten dugun bakoitzean, psikologo adituren batek gaixotasun berriren bat diagnostikatzen duen aro eroan.

Dena den, pixkanaka hasi gara ohartzen aurrerapenak ez duela zertan izan penak aurreratzea, gelditu, arnasa hartu eta oinarrirantz urrats bat ematea ere aurrera egiteko modua izan daitekeela batzuetan. Hasi gara ohartzen bizitza osasuntsua eta zoriontsua izateko giltza ez digula lurretik 1.400 argi-urtera aurkitutako Kepler-452b planetak emango, betidanik gure aurrean izan dugunak baizik: ama naturak. Aro ero honetan ere berak eskain diezazkiguke osasun onean egoteko oinarrizko elikagaiak eta baita gaixotzen garenean sendatzeko eta minak baretzeko konposatu miragarriak ere.

Ildo horretatik doa azaltzera noakizun doktore-tesi honen helburu nagusia: ama naturak osasuntsu bizitzeko eskaintzen dizkigun baliabideak hobeto ustiatzeko metodologia analitikoak garatzea, hain zuzen ere. Tesi hau bi zutabetan banatzen da. Lehenengoan, ardo-hondakinetako konposatu bioaktiboak ustiatzeko metodologia garatu genuen. Bigarrengoan, aldiz, kannabisa sendagai gisa erabili ahal izateko bidean urrats ezberdinak eman genituen.

\section{MAHATSAK TXERRITUZ}

Daramagun bizi-erritmoaren ondorioz, industrialki prozesatutako elikagaiak gure eguneroko ogi bilakatu dira, baita horiek duten balio nutrizionalaren galera konpentsatzeko gehigarrien beharra ere. Gehigarri horien artean aurkitzen dira gantz-azido asegabeak eta polifenolak [1].

Gantz-azidoak karbonoz eta hidrogenoz soilik osatutako kate lineal luzea duten molekula organikoak dira, mutur batean karboxilo $(-\mathrm{COOH})$ talde bat dutenak. Karbonoen arteko loturaren arabera, bi multzotan banatzen dira: aseak eta asegabeak. Gantz-azido aseetan karbonoen arteko lo- 
Atzoko baliabideak, biharko osasuna: ardo-hondakinak eta kannabisa

tura bakuna da; hargatik, solidoak dira, eta ehunetan pilatzen direnez, odoleko kolesterol maila igotzearen erantzule dira [2]. Gantz-azido asegabeek, aldiz, karbonoen arteko lotura bikoitz bat dute gutxienez; ondorioz, likidoak dira eta gantz-azido aseen alderantzizko efektua dute, hots, kolesterol maila jaisteko eta, ondorioz, arrisku kardiobaskularra gutxitzeko eta minbizien prebentziorako oinarrizkoak dira [3]

Polifenolak, aldiz, fenol $\left(\mathrm{C}_{6} \mathrm{H}_{5} \mathrm{OH}\right)$ talde bat baino gehiago duten konposatuak dira. Gaitasun antioxidatzaile handia dute, eta horri esker erradikal askeak (elektroi-bikoterik gabeko molekula benetan erreaktiboak) neutralizatzeko gai dira arrisku gutxiagoko konposatuak emanez. Ondorioz, hanturak tratatzeko, minbiziaren prebentziorako edo kosmetikan erabiltzeko baliagarriak dira [4]. Bestalde, garunean oroimena, arreta eta motibazioa gisako funtzioak bultzatzen laguntzen dute [4].

Hondakin agroindustrialen inguruko interesa haziz joan da azken urteetan, balio erantsi handiko albo-produktuen iturri garrantzitsu izan baitaitezke. Ildo horretatik, ardoaren produkzioko hondakinen ustiapena aukera ona izan daiteke, gantz-azido asegabe eta polifenol ugari izateaz gain sortzen den hondakin kopurua izugarria baita, eta ustiapena, berriz, benetan mugatua (1. irudia).
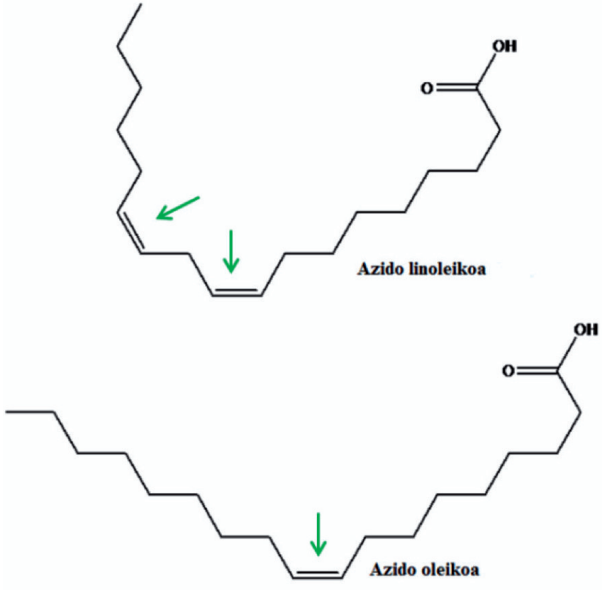<smiles>C/C=C\C(C)(C)C</smiles><smiles>Oc1cc(O)c2c(c1)O[C@H](c1ccc(O)c(O)c1)[C@H](O)C2</smiles>

1. irudia. Ardo-hondakinetan aurkitu genituen gantz-azido eta polifenol nagusien egiturak. Gezi orlegiek gantz-azidoen kate linealeko karbonoen arteko lotura bikoitzak seinalatzen dituzte, gezi urdinek, aldiz, polifenolen fenol taldeak.

Ardo-hondakinetatik konposatu bioaktiboak erauzteko, jariakin gainkritiko bidezko erauzketa erabili genuen [5-6]. Gas bat egoera gainkritikora pasa daiteke ezarritako presioak eta tenperaturak gas bakoitzaren bereizga- 
Oier Aizpurua-Olaizola, Patricia Navarro, Nestor Etxebarria, Aresatz Usobiaga

rri den puntu kritiko bat gainditzen badute. Modu horretan likidoen eta gasen arteko ezaugarriak hartzen ditu. Likidoen antzeko dentsitatea hartzen duenez, disolbatzaile ona da, eta gasen mugikortasuna duenez, erauzketak azkarrago gauzatzen dira [7]

Guk karbono dioxidoa $\left(\mathrm{CO}_{2}\right)$ hautatu genuen gas gisa, inertea izateaz gain erauzketa tenperatura eta presio baxuetan gauzatu daitekeenez, konposatu sentikorrak degradatzea ekiditen baitu. Gantz-azidoak apolarrak dira; polifenolak, ordea, polarrak. Ezberdintasun horretan oinarritzen da konposatu talde bakoitza bere aldetik erauzteko garatu genuen metodoa (2. irudia).
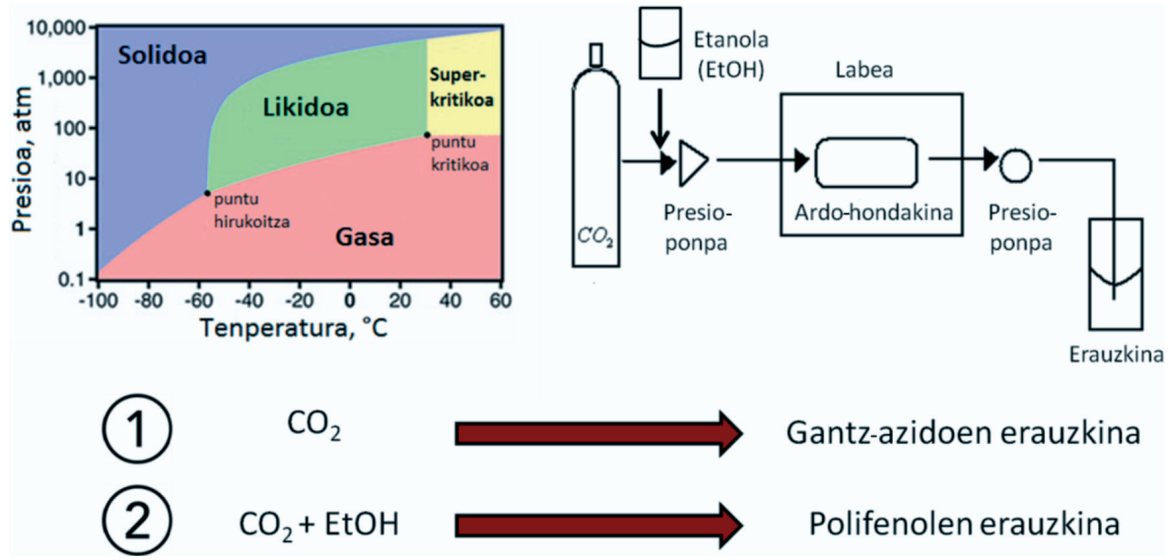

2. irudia. $\mathrm{CO}_{2}$-aren fase-diagrama eta erabilitako jariakin gainkritiko bidezko erauzketaren azalpen eskematikoa. Lehen urratsean, $\mathrm{CO}_{2}$ (apolarra) soilik erabiliz, ardo-hondakinetatik gantz-azidoak erauztea lortu genuen, eta bigarren urratsean albo-disolbatzaile gisa etanola (polarra) gehituz, polifenolak erauztea.

Zoritxarrez, polifenolak erraz degrada daitezke argiaren, tenperaturaren, oxigenoaren eta aktibitate entzimatikoen ondorioz. Arazo hori konpontzeko, zurrusta-bibrazio bidezko mikrokapsularatze-teknika bat garatu genuen (3. irudia) $[6,8]$.

Kapsulak eratzerako orduan, 4 aldagai nagusi optimizatu genituen: fluxu laminarra osatzeko ezarririko presioa, tantatxoak osatzeko bibrazioaren maiztasuna eta horiek dispertsatzeko aplikaturiko boltajea, eta gogortze-disoluziora zegoen distantzia. Aldagaiak 150 eta $300 \mu \mathrm{m}$-ko zurrustentzat optimizatu genituen, emango zaien aplikazioaren araberako tamaina ezberdineko mikrokapsulak izatea komeni baita (4. irudia). 


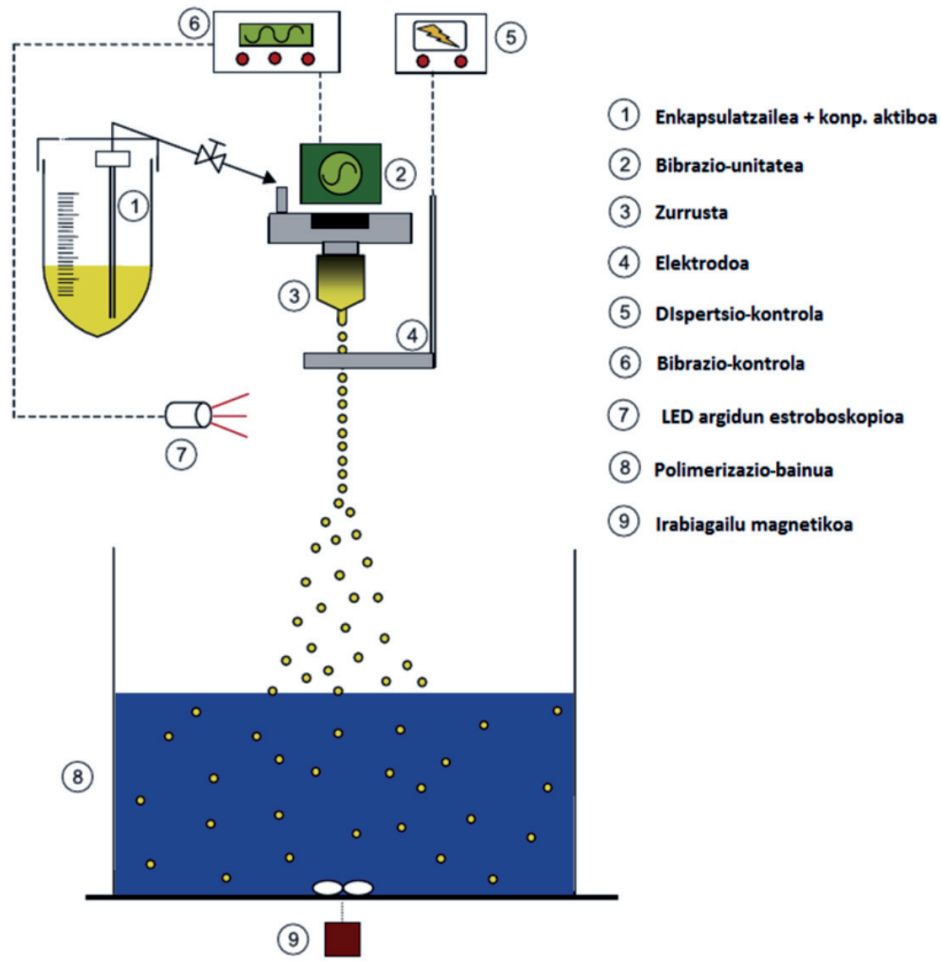

3. irudia. Erabilitako kapsularatze-sistemaren azalpen eskematikoa. Polifenolak agente kapsulatzaile gisa hautatu genuen alginatoarekin nahastu (1), eta nahastearen fluxu laminar bat zulo txiki batetik pasarazten da (3), aplikaturiko bibrazioari (2) esker tanta ñimiñoak osatuz. Boltaje bat ezartzean, (4) tanta horiek dispertsatu egiten dira eta kaltzio klorurozko gogortze disoluziora erortzean, (8) mikrokapsulak osatzen dira.
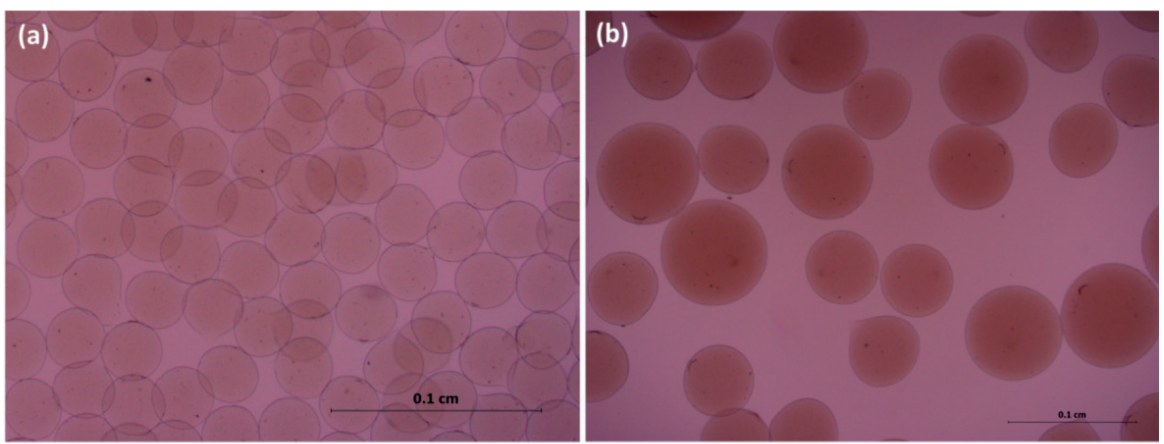

4. irudia. Mikroskopio optiko bidez ateratako argazkiak. (a) $150 \mu \mathrm{m}$-ko eta (b) $300 \mu \mathrm{m}$-ko zurrustekin baldintza optimoetan lortutako mikrokapsulak. 
Oier Aizpurua-Olaizola, Patricia Navarro, Nestor Etxebarria, Aresatz Usobiaga

Sortutako mikrokapsulak liofilizazio bidez lehortu eta haien egonkortasuna aztertu genuen 6 hilabeteetan zehar. Hala, mikrokapsularatzeari esker, giro-tenperaturan polifenolen degradazioa 33 aldiz mantsotzea lortu genuela ikusi genuen.

Modu horretan, ardo-hondakinetatik bi produktu interesgarri lortu genituen, batetik, gantz-azido asegabeetan aberatsa den erauzkina eta bestetik, egonkortasun handiko polifenol mikrokapsulak. Bide hori ardo-hondakinei irteera emateko aukera ona izan daiteke. Arrazoia izango du, azkenean, hondakinak txerrikeria bat direla dioenak, kasu honetan ere, txerrian bezala, dena aprobetxa baitaiteke.

\section{KANNABISA: AGERIKO ALTXOR EZKUTUA}

Lur azpiko altxorrak ondo ezkutatuta eta mila tranpaz eta amarruz babestuta daudela erakutsi izan digu Hollywood-ek; egon bada, ordea, lur azpitik bere kabuz irteten den altxorrik ere. Kannabisaz ari natzaizu. Gaur egun ezagunak dira bere hainbat ezaugarri eta erabilera, gosea piztea, kimioterapia errazago jasateko efektu antiemetikoa, min neuropatiko kronikoari aurre egitea eta esklerosi anizkoitza zein glaukoma tratatzeko erabiltzea, esaterako [9-10]. Bestalde, geroz eta ikerketa gehiagok egiaztatzen dute kannabisa edo bere konposaturen bat lagungarria izan daitekeela minbizi jakin batzuk sendatzeko, epilepsia tratatzeko eta alzheimerrari, Hungtintonen gaixotasunari, diabetes kasuei zein Touretten sindromeari aurre egiteko [10-11]. Oraindik bidearen zati handi bat egiteke dago, ordea.

Kannabisa ez da batere sinplea. 554 konposatutik gora ditu, horien artean 113 kannabinoide eta 120 terpeno. Kannabinoide bakoitzak aktibitate terapeutiko ezberdina du, askorena ez dago oraindik guztiz zehaztuta, ordea. Horretaz gain, euren artean eragin sinergikoa gertatzen da; esaterako, jakina da kannabidiolak (CBD) tetrahidrokannabinolaren (THC) eragin euforikoa modulatzen duela. Hori gutxi ez eta terpenoek, lurrinaren erantzule izateaz gain, hainbat efektu eragiten dituzte eta kannabinoideekin sinergian joka dezakete [12].

Kontuak hala, kannabis barietate jakinak aplikazio jakinekin lotzeko beharrezkoa izango da konposatu guztien aktibitatea eta sinergia-efektuak ezagutzea, baita profil kimikoaren araberako sailkapen berri bat finkatzea ere. Bestalde, saiakera klinikoetan kontzentrazio/efektu erlazioak aztertzeko ezinbestekoa da gorputzeko jariakin biologikoetan kannabinoideen eta euren metabolitoen kontzentrazio zehatzak neurtzeko metodo fidagarriak edukitzea.

Ildo horretan, hiru urrats garrantzitsu eman genituen. Batetik, landareak euren efektu fisiologikoekin lotzeko lagungarria izan daitekeen kannabinoi- 
Atzoko baliabideak, biharko osasuna: ardo-hondakinak eta kannabisa

deen hatz-marka deiturikoa zehazteko metodo bat garatu genuen [13-14]. Bestetik, gernuan eta plasman kannabinoideak eta euren metabolitoak kuantifikatzeko metodo bat ere garatu genuen [13, 15]. Azkenik, ikerketetan beharrezkoak izango diren konposatu puruen ekoizpena optimizatzeko eta horiek landareen hazkuntzan zehar duten garapena ulertzeko azterketa bat gauzatu genuen $[13,16]$.

Kannabinoideen hatz-marka lortzeko, likido kromatografiari loturiko fragmentazio bikoitzeko masa-espektometria (HPLC-MS/MS) erabili genuen. Bertan, kannabis erauzkina fase geldikor batetik pasarazi genuen disolbatzaile baten laguntzaz, hala konposatuak, fase geldikorrarekiko eta disolbatzailearekiko afinitate ezberdina dutenez, elkarrengandik bananduz. Ostean, banandutako konposatuei boltaje bat aplikatu genien, eta bakoitzak osatzen dituen zatiak aztertuz erauzkineko kannabinoide ugarienak identifikatu genituen (5. irudia).

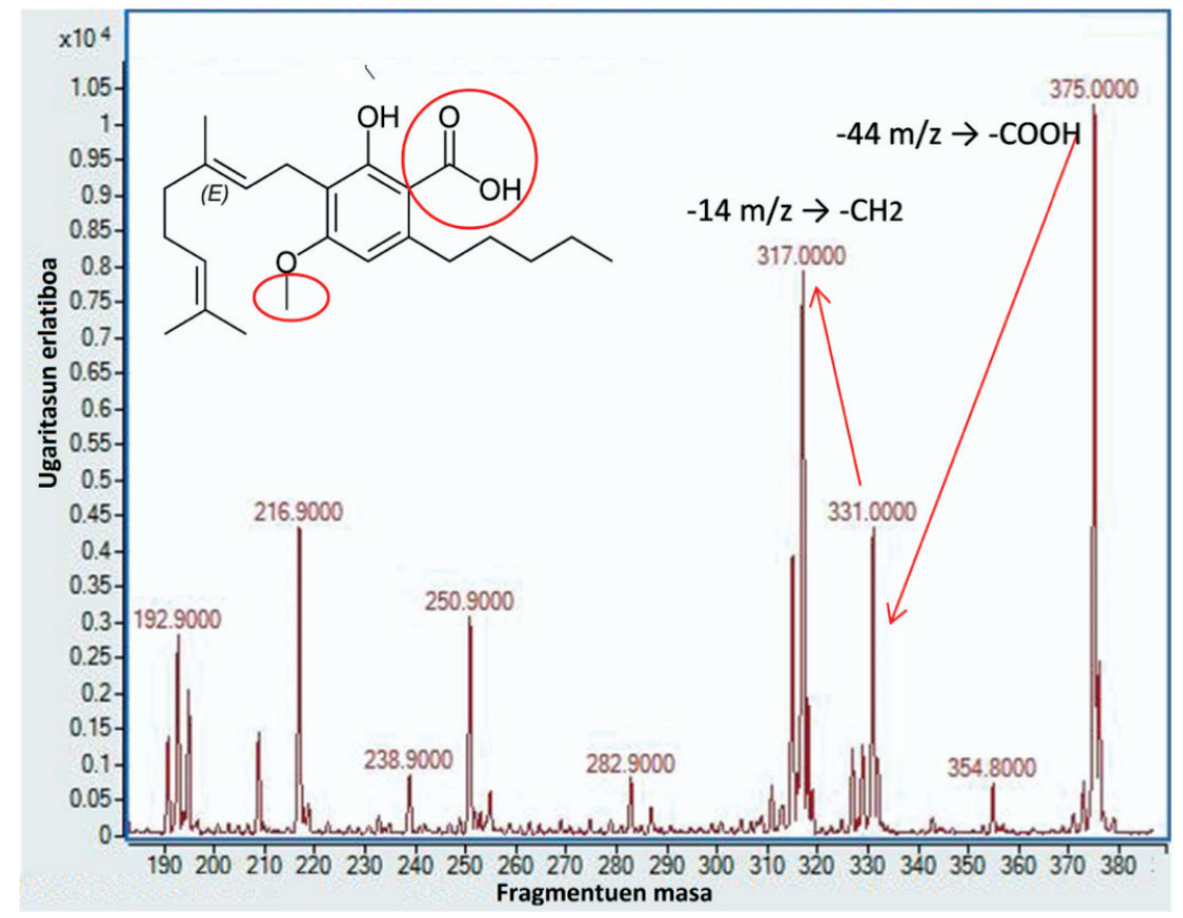

5. irudia. Kannabinoideen identifikazio-prozesuaren adibide bat. 44 masa-unitateko galerak kannabinoideak talde karboxiliko bat galdu duela adierazten du, 14 unitateko galerak, aldiz, metilo talde baten galera. Zati ezberdinak aztertuz eta bibliografiaren laguntzaz, konposatu hori kannabigerol monometil eter azidoa dela ondorioztatu genuen esaterako. Guztira hamahiru kannabinoide identifikatu genituen modu horretan. 
Oier Aizpurua-Olaizola, Patricia Navarro, Nestor Etxebarria, Aresatz Usobiaga

Hatz-marka osatzeko, identifikaturiko kannabinoideen kontzentrazioak osagai nagusien analisi bidez tratatu genituen. Tratamendu horrek elkarrekiko korrelazioa duten aldagai multzo bat korrelaziorik gabeko aldagai kopuru txikiago batean laburbiltzen du, hala agerian ez dauden aldagaiak aurkitzen lagunduz.

Garatutako metodologia balioztatzeko, 30 landare neurtu genituen. Modu horretan barnean eta kanpoan hazitako landareen hatz-markak ezberdinak direla frogatu genuen (6. irudia). Behin kannabinoideen aktibitateak eta sinergia-efektuak ondo ulertuta, metodo horrek landare batek izan ditzakeen efektuak aurreikusteko balio dezake.

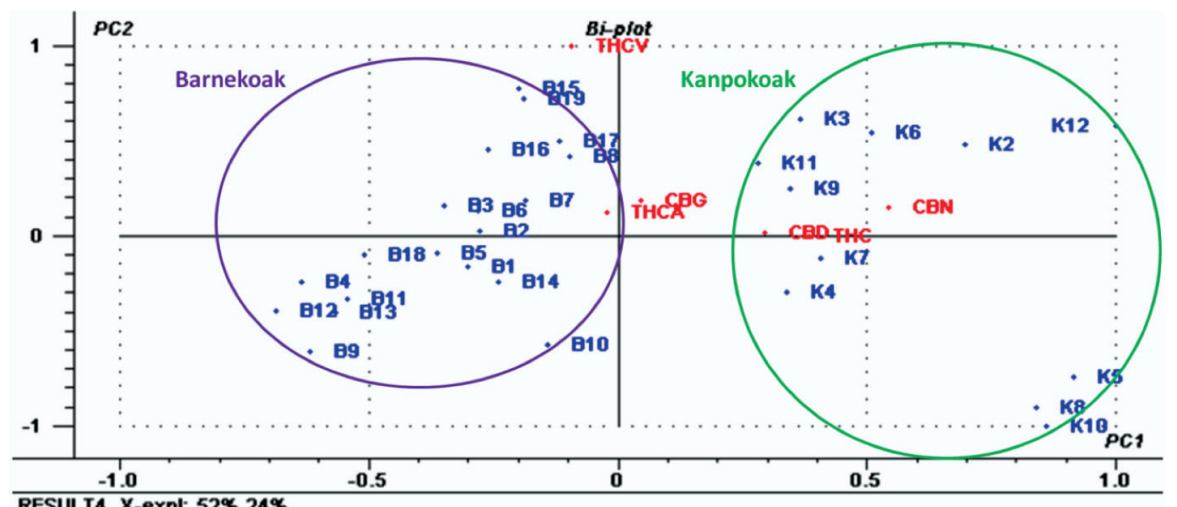

RESULT 4, X-expl: $52 \%, 24 \%$

6. irudia. 30 kannabis landare ezberdinen 6 kannabinoide nagusien kontzentrazioa kontuan hartuz, osagai nagusien analisi bidez erdietsitako banaketa. (B: barnean hazitako landareei dagokie; K: kanpoan hazitako landareei dagokie). $\mathrm{X}$ ardatza lehen osagai nagusiari dagokio (PC1) eta $\mathrm{Y}$ ardatza bigarren osagai nagusiari (PC2).

Arestian aipatu bezala, bigarren urratsean kannabinoideak eta horien metabolitoak neurtzeko metodologia garatu genuen. Konposatu horiek hein batean glukuronizatu egiten dira gorputzean, ordea, bakoitzaren ezaugarrien araberako glukuronido lotura ezberdinak (eter- eta ester-loturak) osatuz, gainera [17]. Kannabinoideen eta metabolitoen kontzentrazio totala jakiteko beharrezkoa da lehenik eta behin lotura glukuronido horiek haustea. Ildo horretatik, lehenik eta behin lotura horiek hausteko hidrolisi-metodoa garatu genuen. Hala, eter-loturak hausteko hidrolisi entzimatikoa beharrezkoa dela ikusi genuen, eta ester-loturak hausteko, aldiz, hidrolisi alkalinoa. Ondorioz, hidrolisi entzimatiko-alkalino bikoitza hautatu genuen laginen aurretratamendu gisa, lotura glukuronido guztien \% 100 haustea ziurtatzen baitu. Behin hidrolisi-metodoa zehaztuta, analisi-metodoa garatu genuen HPLC-MS/MS bidez. Metodoaren detekzio-mugak $1 \mathrm{ng} / \mathrm{mL}-$ tik behe- 
rakoak izan ziren analito guztientzat, eta balioztatutako metodoa kannabis erabiltzaileen gernu- eta plasma-laginak aztertzeko erabili zen behar bezalako emaitzak erdietsiz (7. irudia).
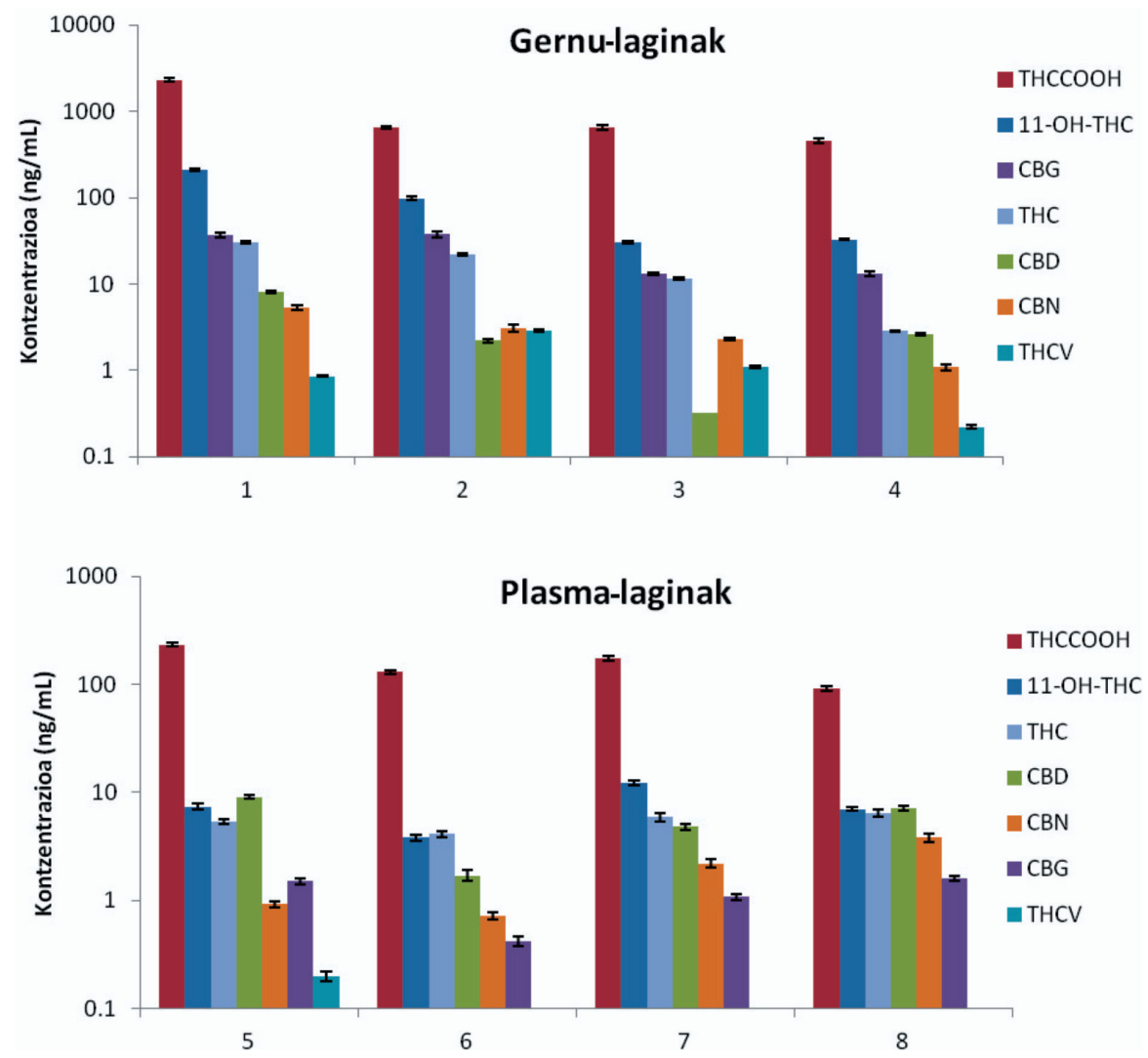

7. irudia. kannabis erabiltzaileen gernu- eta plasma-laginetan aurkitutako kannabinoideen (THC, CBD, CBN, CBG eta THCV) eta horien metabolitoen (THCCOOH eta 11-OH-THC) kontzentrazioak.

Hirugarren urratsean, kannabinoideek eta terpenoek landareen hazkuntzan zehar duten garapena aztertu genuen 3 kimiotipo garrantzitsuenetan: THC kontzentrazio altuko landareak (I.), CBD kontzentrazio altuko eta THC baxuko landareak (III.), eta bi konposatu horien kontzentrazio parekoa duten landareak (II.) (8. irudia). Oraintsu arte, I. kimiotipoko landareak soilik zeuden hedatuta, erabilera ludikoan bilatzen den efektu psikoaktiboaren erantzule nagusia baita THCa. Dena den, azken urte hauetan II. eta III. kimiotipoko landareak indar handia hartzen hasi dira, sendagarri gisa erabiltzeko batez ere. 
Oier Aizpurua-Olaizola, Patricia Navarro, Nestor Etxebarria, Aresatz Usobiaga
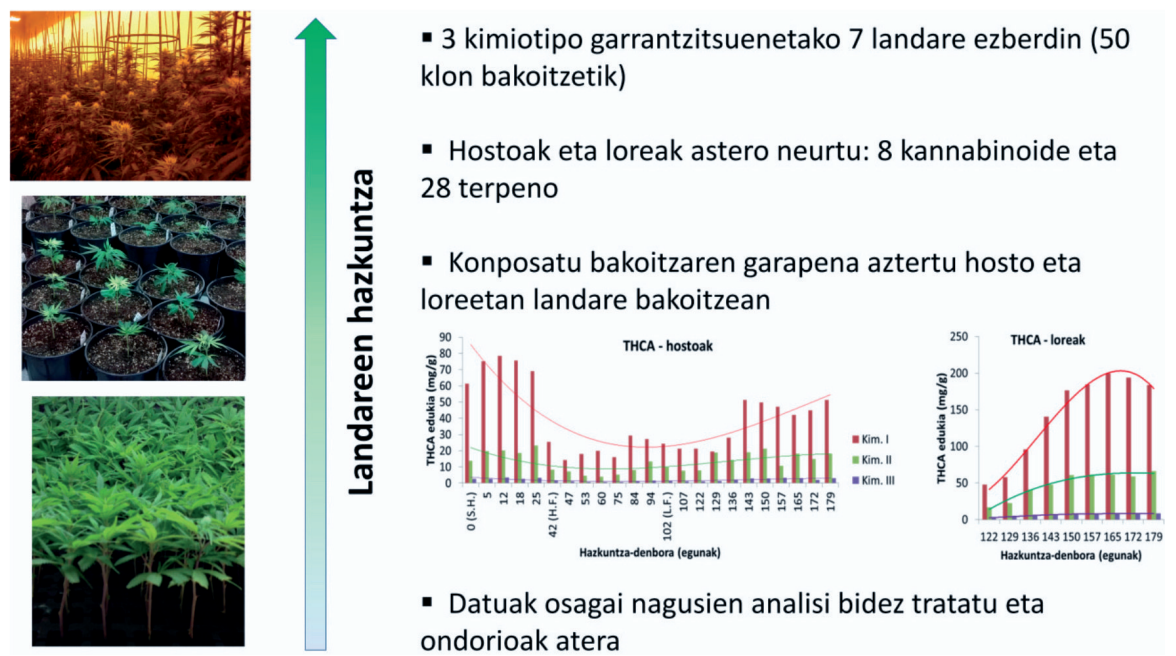

8. irudia. Kannabinoideek eta terpenoek kannabis landare ezberdinen hazkuntza-prozesuan zehar duten garapena aztertzeko gauzatutako ikerketaren laburpen grafikoa.

Konposatuen garapena aztertuta, hainbat ondorio interesgarri atera genituen. Batetik, landarearen kimiotipoa hasieratik agerikoa eta denboran zehar egonkorra dela. Horrek auzitegietan eragin dezake, gaur egun kannabis plantazio bat legez kontrakoa (THC kontzentrazio altua) den jakiteko, landareak guztiz hazi arte itxaron behar baita.

Bestalde, konposatuen kontzentrazio maximoak noiz gertatzen diren aurkitu genuen, II. eta III. kimiotipoko landareek denbora gehiago behar dutelarik konposatu gehienen maximora iristeko. Horrez gain, ezberdintasunak aurkitu genituen monoterpenoen (10 karbonoko terpenoak) eta seskiterpenoen (15 karbonoko terpenoak) artean ere, lehenengoak loratze-fasean ugaritzen doazelarik eta bigarrengoak ez. Azkenik, kimiotipo bakoitzaren bereizgarri diren terpenoak ere aurkitu genituen, hori kannabinoideen eta terpenoen arteko sinergiak ikertzeko lagungarria izan daitekeelarik.

\section{ONDORIOAK}

Tesiaren lehen zatian, ardo-hondakinen balioa handitzeko metodologia bat garatu genuen. Lehenik eta behin, ardo-hondakinetatik polifenolak eta gantz-azidoak, bakoitza bere aldetik, erauztea lortu genuen jariakin gainkritiko bidezko erauzketa erabilita. Ostean, polifenolen egonkortasuna hobetzeko mikrokapsularatze-teknika bat garatu genuen. Modu horretan ardo-hondakinetatik bi produktu interesgarri erdietsi genituen, batetik, 
Atzoko baliabideak, biharko osasuna: ardo-hondakinak eta kannabisa

gantz-azido asegabeetan oso aberatsa den erauzkina eta bestetik, egonkortasun handiko polifenol mikrokapsulak.

Bigarren zatian, kannabisa sendagai bezala erabili ahal izateko bidean lagungarriak izan daitezkeen 3 urrats eman genituen. Alde batetik, landare jakinak aplikazio jakinekin lotzeko landareen kannabinoideen hatz-marka osatzeko metodo bat garatu genuen. Bestetik, saiakera klinikoetan kontzentrazio/efektu erlazioak aztertu ahal izateko, gernuan eta plasman kannabinoideak eta euren metabolitoak kuantifikatzeko metodo sentikor bat garatu genuen. Azkenik, landare ezberdinen hazkuntza-prozesuetan zehar kannabinoideek eta terpenoek duten garapena aztertu genuen, kontzentrazio maximoak noiz aurkitzen diren ezarriz eta kimiotipo bakoitzaren ezaugarri diren terpenoak zeintzuk diren aurkituz. Azken hori kannabinoideen eta terpenoen arteko sinergiak ulertzeko lagungarria izan daiteke.

\section{ESKER ONAK}

Egileek esker ona adierazi nahi diete IDOKI SCF S.L. enpresari jariakin gainkritiko bidezko erauzketa-sistema erabiltzen uzteagatik; Ostatu eta Mokoroaga ardotegiei ikerketarako beharrezko materiala eskaintzeagatik; Renovatio fundazioari eta Sevillako biomedikuntza institutuari kannabis erabiltzaileen gernu- eta plasma-laginak emateagatik; Aifame $\mathrm{GmbH}$ enpresari landareen hazkuntzaren ikerketarako beharrezko material eta baliabide guztiak eskaintzeagatik; eta Eusko Jaurlaritzari SAIOTEK (SAI12/136) proiektuagatik, talde kontsolidatuko laguntzagatik (IT742-13) eta O. Aizpurua-Olaizolaren aurre-doktoregoko bekarengatik.

\section{BIBLIOGRAFIA}

[1] SHAHIDI F. 2012. «Nutraceuticals, functional foods and dietary supplements in health and disease». J. Food Drug Anal., 20, 226-230.

[2] MENSINK R.P. 2013. Fatty Acids: health effects of saturated fatty acids. In ALLEN L.H., PRENTICE A., CABALLERO B., (Eds.), «Encyclopedia of Human Nutrition». Academic Press, Massachusetts, USA, 215-219 or.

[3] GNONI G.V., NATALI F., GEELEN M.J.H., SICULELLA L. 2010. Oleic acid as an inhibitor of fatty acid and cholesterol synthesis. In PREEDY V.R., WATSON R.R., (Eds.), "Olives and olive oil in health and disease prevention». Academic Press, Massachusetts, USA, 1365-1373 or.

[4] WATSON R.R., PREEDY V.R., \& ZIBADI S., (Eds.). 2013. «Polyphenols in Human Health and Disease». Academic Press, Massachusetts, USA.

[5] AIZPURUA-OLAIZOLA O., ORMAZABAL M., VALLEJO A., OLIVARES M., NAVARRO P., ETXEBARRIA N., USOBIAGA A. 2015. «Op- 
Oier Aizpurua-Olaizola, Patricia Navarro, Nestor Etxebarria, Aresatz Usobiaga

timization of supercritical fluid consecutive extractions of fatty acids and polyphenols from Vitis Vinifera grape wastes». J. Food Sci., 80, 101-107.

[6] AIZPURUA-OLAIZOLA O., VALLEJO A., OLIVARES M., NAVARRO P., ETXEBARRIA N., USOBIAGA A. 2015. «Mahatsak txerritzen». Ekaia, 29, 61-72.

[7] MENDIOLA J.A., HERRERO M., CASTRO-PUYANA M., IBAÑEZ E. 2013. Supercritical Fluid Extraction. In ROSTAGNO M.A.; PRADO J.M. (Eds.) «Natural Products Extraction». Royal Society of Chemistry, London, 196-230.

[8] AIZPURUA-OLAIZOLA O., NAVARRO P., VALLEJO A., OLIVARES M., ETXEBARRIA N., USOBIAGA A. 2016. «Microencapsulation and storage stability of polyphenols from Vitis vinifera grape wastes». Food Chem., 190, 614-621.

[9] WHITING P.F., et al. 2015. «Cannabinoids for Medical Use: A Systematic Review and Meta-analysis». JAMA, 313, 2456-2473.

[10] IZZO A.A., BORRELLI F., CAPASSO R., DI MARZO V., MECHOULAM R. 2009. «Non-psychotropic plant cannabinoids: new therapeutic opportunities from an ancient herb». Trends Pharmacol. Sci., 30, 515-527.

[11] VELASCO G., SÁNCHEZ C., GUZMÁN M. 2012. "Towards the use of cannabinoids as antitumour agents». Nat. Rev. Cancer, 12, 436-444.

[12] RUSSO E.B. 2011. «Taming THC: potential cannabis synergy and phytocannabinoid-terpenoid entourage effects». Brit. J. Pharmacol., 163, 1344-1364.

[13] AIZPURUA-OLAIZOLA O., OMAR J., OLIVARES M., NAVARRO P., ETXEBARRIA N., USOBIAGA A. 2016. «Kannabisa: ageriko altxor ezkutua». Ekaia, 30, 7-18.

[14] AIZPURUA-OLAIZOLA O., OMAR J., NAVARRO P., OLIVARES M., ETXEBARRIA N. USOBIAGA A. 2014. «Identification and quantification of cannabinoids in cannabis sativa L. plants by high performance liquid chromatography-mass spectrometry». Anal. Bioanal. Chem., 406, 75497560 .

[15] AIZPURUA-OLAIZOLA O., ZARANDONA I., ORTIZ L., NAVARRO P., ETXEBARRIA N., USOBIAGA A. 2017. «Simultaneous quantification of major cannabinoids and metabolites in human urine and plasma by HPLC-MS/MS and enzyme-alkaline hydrolysis». Drug Test. Anal., 9, 636633.

[16] AIZPURUA-OLAIZOLA O., SOYDANER U., ÖZTÜRK E., SCHIBANO D., SIMSIR Y., NAVARRO P., ETXEBARRIA N., USOBIAGA A. 2016. «Evolution of the Cannabinoid and Terpene Content during the Growth of Cannabis sativa Plants from Different Chemotypes». J. Nat. Prod., 79, 324-331.

[17] ABRAHAM T.T., LOWE R.H., PIRNAY S.O., DARWIN W.D., HUESTIS M.A. 2007. «Simultaneous GC-EI-MS Determination of $\Delta 9$ Tetrahydrocannabinol, 11-Hydroxy- $\Delta$ 9-Tetrahydrocannabinol, and 11-nor9-Carboxy- $\Delta$ 9-Tetrahydrocannabinol in Human Urine Following Tandem Enzyme-Alkaline Hydrolysis». J. Anal. Toxicol., 31, 477-485. 